\title{
SOBRE O TRATAMENTO LEGAL DO OFENDIDO NO PROCESSO PENAL: UMA ANÁLISE COMPARATIVA ENTRE O DIREITO BRASILEIRO E O NORTE-AMERICANO
}

\author{
ON THE LEGAL TREATMENT OF THE VICTIM IN CRIMINAL PROCEDURE: \\ A COMPARATIVE ANALYSIS BETWEEN BRAZILIAN AND AMERICAN LAW
}

\section{SOBRE EL TRATAMIENTO JURÍDICO DE LA VÍCTIMA EN EL PROCESO PENAL: UN ANÁLISIS COMPARATIVO ENTRE EL DERECHO BRASILEÑO Y EL ESTADOUNIDENSE}

\author{
ANDRÉ RIBEIRO GIAMBERARDINO \\ https://orcid.org/0000-0003-4018-7730 / http://lattes.cnpq.br/0997816643711510 / andrergiam@gmail.com \\ Universidade Federal do Paraná \\ Curitiba, PR, Brasil

\begin{abstract}
Mário Edson Passerino Fischer da Silva https: / / orcid.org/0000-0003-0935-3681 / http:/ / lattes.cnpq.br/0243841902750302 / mariofmppr@gmail.com Universidade Federal do Paraná Curitiba, PR, Brasil
\end{abstract}

\begin{abstract}
RESUMO
Objetiva-se comparar panoramicamente os direitos e o papel do ofendido no processo penal brasileiro e americano. A metodologia pauta-se em revisão bibliografica e análise comparativa entre os marcos legais e jurisprudenciais. 0 artigo é dividido em três partes: a compreensão dos marcos normativos em cada país; as formas de intervenção do ofendido no processo penal e os direitos garantidos ao ofendido e os remédios jurídicos para assegurá-los. Conclui-se que o direito norte-americano mostra-se mais aberto à participação direta do ofendido no processo, prevendo as declarações de impacto, o direito de conferência com o promotor e o direito de consulta no âmbito do plea bargaining.; mas quanto à intervenção processual indireta, o direito brasileiro oferece ao ofendido chances mais potentes. Ambos, todavia, imersos em uma racionalidade punitiva e que deve ser diferenciada da alternativa, mais promissora, das práticas restaurativas.
\end{abstract}

Palavras-chave: Direito comparado; Vítima; Processo penal; Negociação penal.

\section{ABSTRACT}

The aim is to make a panoramic comparison between the rights and the role of the victim in the Brazilian and American criminal proceedings. The methodology is based on literature review and the comparison between the legal and jurisprudential frameworks. The article is divided into three parts: the understanding of the normative frameworks in each country; the forms of intervention of the victim in the criminal process and the rights guaranteed to the victim and the legal remedies to ensure them. We conclude that US law is more open to the direct participation of the victim in the process, providing for impact statements, the right to conference with the prosecutor and the right of consultation in the context of plea bargaining; but with regard to indirect procedural intervention, Brazilian law offers the victim more powerful chances. Both, however, are immersed in a punitive rationality and should be differentiated from the alternative, more hopeful, of restorative justice practices.

Keywords: Comparative law; Victim; Criminal procedure; Criminal negotiation. 


\section{RESUMEN}

El objetivo es hacer una comparación panorámica entre los derechos y el papel de la víctima en los procesos penales brasileños y estadounidenses. La metodología se basa en la revisión bibliográfica e la comparación entre los marcos legales y jurisprudenciales. El artículo se divide en tres partes: la comprensión de los marcos normativos de cada país; las formas de intervención de la víctima en el proceso penal y los derechos garantizados a la víctima y los recursos legales para garantizarlos. Concluimos que la ley estadounidense está más abierta a la participación directa de la víctima en el proceso, previendo declaraciones de impacto, el derecho a una conferencia con el procurador y el derecho a la consulta en el contexto de la negociación de los cargos; pero en lo que respecta a la intervención procesal indirecta, la ley brasileña le ofrece a la víctima oportunidades más poderosas. Ambos, sin embargo, están inmersos en una racionalidad punitiva y deben diferenciarse de las prácticas alternativas, más prometedoras, de restauración.

Palabras clave: Derecho comparado; Víctima; Procedimiento penal; Negociación penal.

\section{SUMÁRIO}

INTRODUÇÃO; 1 DA CONCEPÇÃO JURÍDICA DO OFENDIDO NO BRASIL E NOS ESTADOS UNIDOS; 2 OS DIREITOS DE INTERVENÇÃO DO OFENDIDO NA GESTÃO PROCESSUAL DO CASO PENAL; 3 OS DIREITOS DAS VÍTIMAS PARA ALÉM DO PROCESSO PENAL; CONCLUSÃO; REFERÊNCIAS.

\section{INTRODUÇÃO}

Partindo de revisão bibliográfica sobre o estado da arte do tema e do levantamento comparativo de marcos legais e decisões judiciais paradigmáticas acerca do tratamento da vítima de crimes, o presente artigo tem como escopo comparar os direitos e o papel do ofendido no processo penal brasileiro e norte-americano, especificamente nos casos relativos às ações penais públicas, ou seja, cuja titularidade do exercício do direito de ação pertença ao Estado, como é regra.

Optou-se por tal recorte porque nas ações penais privadas, tanto nos Estados Unidos como no Brasil, o ofendido, ainda que inserido em um contexto mais peculiar ${ }^{1}$ do que no processo civil, recebe o tratamento jurídico de parte. Além desse motivo, tem-se que na última década vem se fortalecendo no Brasil as políticas institucionais de incentivo à autocomposição

\footnotetext{
1 Por exemplo, ainda que o ofendido seja considerado o titular da ação penal privada, o art. 45 e 46, §2, do Código de Processo Penal Brasileiro autorizam que o Ministério Público, no prazo de 3 (três dias) adite a queixa e intervenha e todos os atos do processo.

2 Sobre o tema ver a Resolução $n^{\circ} 125 / 2010$ do Conselho Nacional de Justiça (CNJ), que institui a política nacional judicial de autocomposição, a Resolução $n^{\circ} 225$ do CNJ, que regulamenta a operacionalização de práticas restaurativas no âmbito judicial e a Resolução $\mathrm{n}^{\circ} 118$ de 2014 do Conselho Nacional do Ministério Público, que estipula a política nacional de incentivo ao uso de técnicas autocompositivas no âmbito do Ministério Público. Em: BRASIL. Resolução $n^{\circ} 125$ de 29 de novembro de 2010. Brasília: Conselho Nacional de Justiça, 2010.BRASIL. Resolução $n^{\circ}$ 225, de 31 de maio de 2016. Brasília: Conselho Nacional de Justiça, 2016. BRASIL. Resolução $n^{\circ} 118$ de $1^{\circ}$ de dezembro de 2014. Brasília: Conselho Nacional do Ministério Público, 2014.
} 
inclusive surgindo propostas do gênero na seara dos processos penais de ação pública ${ }^{3}$. Isso implica na necessidade de se prestar maior atenção ao ofendido, pois ele passa a se tornar uma peça chave na formulação da resposta ao caso penal em circunstâncias relativas à operacionalização de práticas restaurativas e mediações penais.

As propostas de inserção de mecanismos dialógicos e negociais no processo penal brasileiro buscam inspiração em sistemas jurídicos de common law. Isso pode ser atestado, por exemplo, pelo uso difundido da metodologia de círculos de construção de paz como práticas restaurativas, tendo-se como referência norte-americana Kay Pranis ${ }^{4}$, ou da colaboração premiada, prevista na Lei 12.850 de $2013^{5}$, ou mesmo do acordo de não-persecução penal ${ }^{6}$, previsto no art. 28-A do Código de Processo Penal, cuja adoção tem forte influência do plea bargaining.

Há, no entanto, diferenças profundas entre as práticas de justiça restaurativa e as negociações envolvendo acordos entre o investigado, ou acusado, e o Ministério Público. No primeiro caso, ao menos idealmente, tem-se o protagonismo da vítima, que interage com o seu ofensor por meio de um espaço comunicativo racionalizado e mediado, podendo ter ingerência na construção de uma resposta ao caso. Nesse approach, o conflito atrelado ao caso penal é gerenciado prioritariamente pelo ofendido, autor da ofensa e seus respectivos apoiadores, tendo os dois primeiros um poder decisório que, posteriormente, seria fiscalizado pelas instituições do Sistema de Justiça. No caso das negociações entre Ministério Público e investigado, ou acusado,

\footnotetext{
${ }^{3}$ Sobre o tema ver o Projeto de Lei Federal $n^{\circ} 7.006$ de 2006, que regulamente a operacionalização e os efeitos jurídicos de práticas restaurativas no âmbito do processo penal brasileiro e atualmente está apensado ao Projeto de Lei Federal de $n^{\circ} 8.045$ de 2010, que propõe um novo Código de Processo Penal e em seu art. 267, inciso IV, acrescentado pela Emenda $n^{\circ}$ 54, aponta a homologação de acordo restaurativo como causa para extinção do processo penal sem resolução de mérito. Tem-se que a emenda é temerária, pois a mera homologação de acordo não significa que este será cumprido. Em: BRASIL. Projeto de Lei $\mathbf{n}^{\circ}$ 7.006 de 2006. Distrito Federal: Câmara dos Deputados, 2006. BRASIL. Projeto de Lei n8.045 de 2010. Distrito Federal: Câmara dos Deputados, 2006.

${ }^{4}$ Sobre o tema ver: PRANIS, Kay; BOYES-WATSON, Carolyn. No Coração da Esperança: guia de práticas circulares. Porto Alegre: Tribunal de Justiça do Estado do Rio Grande do Sul, 2011.

5 “Art. $4^{0} 0$ juiz poderá, a requerimento das partes, conceder o perdão judicial, reduzir em até $2 / 3$ (dois terços) a pena privativa de liberdade ou substituí-la por restritiva de direitos daquele que tenha colaborado efetiva e voluntariamente com a investigação e com o processo criminal, desde que dessa colaboração advenha um ou mais dos seguintes resultados: (...)". Em. BRASIL. Lei $\mathrm{n}^{\circ}$ 12.850, de 2 de Agosto de 2013. Brasília: Congresso Nacional, 2013.

6 "Art. 28-A. Não sendo caso de arquivamento $e$ tendo o investigado confessado formal $e$ circunstancialmente a prática de infração penal sem violência ou grave ameaça e com pena mínima inferior a 4 (quatro) anos, o Ministério Público poderá propor acordo de não persecução penal, desde que necessário e suficiente para reprovação e prevenção do crime, mediante as seguintes condições ajustadas cumulativa e alternativamente (...)”. Em: BRASIL. Lei $n^{\circ} 13.964$, de 2019. Brasília: Congresso Nacional, 2019.
} 
além de existir um claro desbalanceamento de poder entre promotor e suposto autor da ofensa, a participação da vítima, via de regra, não é necessária para a condução da negociação e a palavra final pertence ao agente ministerial. Além disso, na barganha penal, usualmente se negocia uma punição e não uma forma de reparação dos danos causados pelo crime, como no caso da maioria dos acordos restaurativos. Os mecanismos negociais de barganha, no entanto, também permitem que sejam consideradas questões vinculadas à vítima na elaboração dos termos de eventual acordo entre Ministério Público e investigado, ou mesmo que esta seja ouvida para tanto, como será aprofundado adiante.

Neste sentido, os Estados Unidos são uma referência comparativa importante pelo fato de sua experiência ter influenciado a institucionalização brasileira de práticas negociais e dialógicas que afetam o ofendido no Brasil e, principalmente, porque nas últimas décadas tal país vem positivando uma série de direitos relativos às vítimas de crimes.

Ressalva-se, porém, a constatação preliminar de algumas peculiaridades que necessitam ser levadas em conta: o pacto federativo norte-americano resultou em maior autonomia dos entes federados, o que reflete, em razão da Décima Emenda da Constituição norte-americana, na possibilidade desses entes legislarem também sobre matéria penal e processual - o que é, salvo delegação via lei complementar, vedado no Brasil (art. 22, I, CF). Em segundo lugar, o sistema jurídico dos Estados Unidos é fundado na observância de precedentes judiciais (common law), enquanto o sistema brasileiro é centrado no conteúdo da lei escrita (civil law), centralidade essa cada vez mais mitigada pelo ativismo judicial.

Sobre o tratamento processual penal da vítima, tanto a doutrina estadunidense quanto a brasileira recebem críticas por não the conferirem maior relevância. 0 enfoque legislativo e doutrinário foca majoritariamente nas garantias processuais do ofensor, e nem poderia ser diferente, afinal este é o destinatário em potencial da pena e enfrenta, especialmente nos processos penais de natureza pública, todo o aparato institucional investigativo do Estado. Nos Estados Unidos, os movimentos que lutam pelos direitos dos ofendidos exercem grande pressão política, principalmente porque, para além da pressão sobre os congressistas, os promotores e juízes estaduais também são, majoritariamente, providos em seus cargos a partir do voto popular e não gozam de vitaliciedade ${ }^{7}$, o que aumenta as chances desses movimentos influenciarem a agenda de seus gabinetes.

7 Markus Dirk Dubber ressalta que nos Estados Unidos, como regra, as prioridades dos gabinetes de promotores estaduais são guiadas para satisfazer desígnios eleitorais. Neste contexto se insere o fato de que ONGS e grupos de vítimas exercem pressões sobre as promotorias. DUBBER, Markus Dirk. The Victim in 
Segundo Dubber, a emergência dos movimentos das vítimas nos EUA foi alimentada por discursos políticos populistas de combate à criminalidade e pautou-se primeiramente em uma perspectiva punitivista voltada à incapacitação dos autores de crimes $^{8}$. Na prática, a consequência inicial de tais articulações contribuiu para a onda de encarceramento cujas drásticas consequências foram sentidas apenas no final dos anos 90 , não tendo tais movimentos, neste primeiro momento, conquistado reformas sistêmicas, mas sim previsões normativas em sua maioria de caráter simbólico.

De 1970 a 1980, os ofendidos por crimes nos Estados Unidos pleiteavam direitos através de marcos legais pontuais, como o direito à restituição e ao tratamento com justiça e respeito pelas autoridades ${ }^{9}$. Essa é a chamada "primeira onda das reivindicações das vítimas nos EUA". 0 segundo estágio começou em 1982, com um relatório do presidente da força tarefa ligada aos direitos das vítimas, com 66 recomendações, incluindo uma proposta de emenda à Constituição Federal $^{10}$. Durante essa segunda etapa foram aprovadas 33 emendas constitucionais referentes à positivação de direitos e garantias de proteção às vítimas de crimes, porém todas em âmbito estadual $^{11}$. Beloof afirma que as primeiras duas ondas tiveram como mote a positivação dos direitos dos ofendidos, tendo a primeira influenciado na promulgação de marcos legais e a segunda na aprovação de emendas constitucionais em nível estadual, mas nenhuma logrou êxito em efetivar a observância desses direitos ${ }^{12}$.

A "terceira onda", ainda em curso, caracteriza-se pelo movimento de transformação dessas previsões normativas em direitos de fato, de modo a prover as vítimas de instrumentos

American Penal Law: A Systematic Overview. Buffalo Criminal Law Review: Victim in Penal Law. Bufflalo: Oct. 21, vol. 3:3, p. 3-31, 1999, p. 18-20. Sobre o sistema de eleições no Poder Judiciário, v. também: ZAFFARONI, Eugênio Raúl. Poder Judiciário: Crise, Acertos e Desacertos. São Paulo: Editora Revista dos Tribunais, 1995.

8 DUBBER, Markus Dirk. The Victim in American Penal Law: A Systematc Overview. Buffalo Criminal Law Review, p. 6.

${ }^{9}$ AARONSON, David E. New Rights and Remedies: The Federal Crime Victims Rights Act of 2004. Pace Law Review, Symposium Victims and The Criminal Justice System, Issue 4, v. 28, p. 623-682, Summer 2008, p. 626.

${ }^{10}$ AARONSON, David E. New Rights and Remedies: The Federal Crime Victims Rights Act of 2004. Pace Law Review, p. 627.

11 BELOOF, Douglas E. The Third Wave of Crime Victim's Rights: Standing, Remedy, and Review. BYU Law Review. Article 1, Issue 2, p. 256- 365, 2005, p. 257.

12 BELOOF, Douglas E. The Third Wave of Crime Victim's Rights: Standing, Remedy, and Review. BYU Law Review, p. 257-258. 
processuais e recursos para efetivá-los quando da ocorrência de eventuais violações, que ocorrem, principalmente, pela omissão das autoridades estatais ${ }^{13}$.

No Brasil, movimentos organizados nesse sentido são majoritariamente vinculados aos direitos de categorias específicas de ofendidos, como as mulheres vítimas de violência doméstica e familiar, voltando sua atenção principalmente à criminalização de condutas e aumento de penas, como na aprovação da Lei 11.340/2006 (Lei Maria da Penha) e na inserção da qualificadora de feminicídio no Código Penal (art. 121, \$2 ${ }^{\circ}$, inc. VI), incluído pela Lei $n^{\circ} 13.104$ de 2015. Vale mencionar também o movimento de vítimas de crimes de trânsito, cuja pressão colaborou para a aprovação da Lei $n^{\circ} 13.546 / 2017$, aumentando a pena de homicídio provocado vítimas de crimes vêm se organizando para promover mudanças legislativas em ambos os países, o que contribui para melhor compreensão das ponderações realizadas a seguir.

Assim, o artigo está dividido em três partes. A primeira aborda a compreensão do espaço do ofendido no processo penal, a segunda trata das formas de intervenção do ofendido no processo penal em ambos os países, e a terceira compara previsões normativas e suas formas de efetivação.

\section{DA CONCEPÇÃO JURÍDICA DO OFENDIDO NO BRASIL E NOS ESTADOS UNIDOS}

A palavra vítima vem do latim (victimia e victos) e significa vencido, dominado, abatido $^{14}$, ressaltando a violência e reificação suportadas em face dos atos do autor do crime, que se vale da vítima como um meio de satisfazer algum desejo ou necessidade. No Brasil, os Códigos Penal e Processual Penal não oferecem uma definição geral para o conceito de ofendido. Esses diplomas, portanto, preocupam-se mais com a estipulação dos direitos das vítimas, bem como com a sua vinculação a tipos penais específicos, a partir dos quais torna-se possível verificar quem é o sujeito que sofre as consequências do crime e o titular de tais direitos.

Tal preocupação parece ser mais recorrente em normativas especificamente direcionadas a politicas vinculadas às vítimas. Por exemplo, em 2018, o Conselho Nacional de Justiça (CNJ) publicou a Resolução ${ }^{\circ} 253$ e regulamentou a política judicial de atenção e apoio às vítimas de

13 BELOOF, Douglas E. The Third Wave of Crime Victim's Rights: Standing, Remedy, and Review. BYU Law Review, p.198-299.

14 MAYR, Eduardo. Atualidade e Vitimologia. Em: Kosovski, Ester; MAYR, Eduardo; PIEDADE JR., Heitor. Vitimologia em debate. Rio de Janeiro: Editora Forense, p. 11-23, 1990, p. 11. 
crimes e atos infracionais. Nesta normativa, foi adotada uma concepção de vítima como pessoa que tenha sofrido algum dano físico, moral, patrimonial ou psicológico da prática de crime ou ato infracional praticado por terceiro, dispondo-se que os direitos assegurados a vítima se estenderiam aos cônjuges, companheiros, familiares em linha reta, irmãos e dependentes, como vítimas indiretas da violência.

Em se tratando dos EUA, percebe-se que no âmbito da legislação federal e estadual, busca-se conceituar o ofendido como regra, seja em leis que tratam especificamente dos seus direitos, seja nas Constituições Estaduais, visto que a Constituição Federal nada dispõe acerca de seu tratamento.

O Crime Victims Rights Act de 2004 (CVRA) (Título 18, Parte II, Capítulo 237, do Código $\$ 3771$ dos Estados Unidos), referente à tutela das vítimas em casos de crimes federais, definiu o ofendido como pessoa direta e proximamente lesada pelo resultado de um crime federal ou um crime praticado no Distrito de Columbia ${ }^{15}$. Paradoxalmente, o mesmo diploma restringiu tal definição ressalvando que uma pessoa acusada de um crime, ou respondendo um processo criminal, não gozará de nenhum dos direitos previstos no Ato $^{16}$.

O conceito é impreciso, principalmente pelo uso do termo proximamente. A título de exemplo, no caso Estados Unidos vs. Sharp, a namorada de um acusado de tráfico de drogas requereu à corte o direito de fazer uma declaração de impacto durante o sentenciamento, alegando que sofria abusos do acusado em virtude dele consumir e traficar drogas, razão pela qual seria qualificada como ofendida nos termos do Crime Victims Rights Act ${ }^{17}$. A corte distrital rejeitou o pedido fundamentando que o nexo causal entre o suposto abuso e o fato do acusado vender drogas não foi devidamente demonstrado. Percebe-se então que essa definição abre grande margem de discricionariedade para o Judiciário estipular critérios de delimitação de quem é o ofendido pelo crime.

A Constituição Estadual do Arizona, por sua vez, prevê na seção 2.1 de seu art. $2^{\circ}$ a “Carta de Direitos das Vítimas", e na alínea “c” dessa seção define o ofendido como pessoa contra a qual a infração penal foi cometida ou, no caso de sua morte ou incapacitação, seu

15 Texto original: (e.2.a) "The term "crime victim" means a person directly and proximately harmed as a result of the commission of a Federal offense or an offense in the District of Columbia". Em: ESTADOS UNIDOS. 18, Part II, Chapter 237, of U.S.C. § 3771. Congresso Nacional: 2004.

16 Texto original: (d.1.a) "A person accused of the crime may not obtain any form of relief under this chapter”. Em: ESTADOS UNIDOS. 18, Part II, Chapter 237, of U.S.C. § 3771. Congresso Nacional: 2004.

17 AARONSON, David E. New Rights and Remedies: The Federal Crime Victims Rights Act of 2004. Pace Law Review, Symposium Victims and The Criminal Justice System, Issue 4, v. 28, p. 623-682, Summer 2008, 640-641. 
cônjuge, pai, filho ou outro representante legal, exceto se estes estiverem sob custódia ou corresponderem ao acusado ${ }^{18}$.

Em sua Lei “Rev Stat § 46:1842”, de 1985, o Estado de Louisiana (art. $9^{\circ}$ ), no capítulo que aborda os direitos das vítimas, faz um recorte da sua definição com base em tipos de crime suportados pelo ofendido ${ }^{19}$, o que consequentemente excluiria os direitos daqueles que venham a sofrer outras ofensas criminais.

Observa-se, portanto, especialmente pela força dos movimentos pelos victim rights que a figura do ofendido é recorrente e especificamente abordada na legislação norte-americana.

A teoria do delito substituiu a figura da vítima pelo Estado, que se apropriou do conflito social vinculado ao caso penal, tornando-o sujeito passivo do crime (nos casos já discriminados) e abstraindo a proteção direta da vítima à ideia de que a norma penal teria como fim salvaguardar interesses de ordem coletiva. ${ }^{20}$ Essa é a base do que no Brasil designamos "teoria do bem jurídico".

Não se adentrará na reflexão histórica e sociológica sobre a apropriação institucional do conflito pelo Estado, nem na substituição da vítima, ou na racionalização e processualização do conflito pela exclusão do processo decisório do caso penal. Tal questão é complexa e merece um trabalho próprio para sua abordagem, de modo que realizar essa discussão de forma tangencial culminaria na irreal leitura positivista do ofendido no direito, que descreve (i) a sua exclusão como um resultado necessário das “conquistas civilizatórias" de um direito processual democrático e racional, o qual extirpa de si as paixões e o desejo de vingança, ou (ii) trata do redescobrimento da relevância do ofendido na tutela de casos penais mediante a glorificação de um passado colorido ${ }^{21}$, mas contextualmente diverso do presente

Basta identificar que o discurso jurídico que respalda atualmente a perpetuação do ofendido em uma posição secundária é aquele atrelado à ideia do Estado como sujeito passivo do crime e do crime como previsão que busca respaldar determinados valores e interesses (presumidamente) coletivos.

18 ESTADO DO ARIZONA. Constituição Estadual do Arizona. Congresso Estadual do Arizona: 1911.

19 Texto original: (9) "Victim" means a person against whom any of the following offenses have been committed: (a) Any homicide, or any felony offense defined or enumerated in R.S. 14:2(B). (b) Any sexual offense. (c) The offenses of vehicular negligent injuring and first degree vehicular negligent injuring. (d) Any offense against the person as defined in the Criminal Code committed against a family or household member as defined in R.S. 46:2132(4) or dating partner as defined in R.S. 46:2151(B). Em: LOUISIANA. Rev Stat § 46:1842. Congresso Estadual de Louisiana: 1985.

20 CHRISTIE, Nils Conflict as property. The British Journal of Criminology, Oslo, vol. 17, 1977, p. 5-7.

21 CORDEIRO, Euller Xavier Cordeiro. A participação da Vítima no Processo Penal. Franca: Dissertação apresentada à Faculdade de Ciências Humanas e Sociais da Universidade Estadual Paulista, 2014, p. 16-20. 
0 ofendido, portanto, representa aquele que diretamente foi alvo ou sofreu as consequências do ato criminoso, e embora o sujeito passivo do ato, para a doutrina, seja o Estado, a legislação norte-americana e brasileira recepcionam formas diretas e indiretas da intervenção desse no âmbito do processo penal e da fase que o precede.

\section{OS DIREITOS DE INTERVENÇÃO DO OFENDIDO NA GESTÃO PROCESSUAL DO CASO PENAL}

Segundo Flaviane Magalhães de Barros, há três maneiras da vítima participar no processo penal instaurado a partir de uma ação pública: (i) como agente condicionador do exercício da persecução penal; (ii) como agente controlador da atuação acusatória e (iii) como um colaborador da acusação, podendo ainda atuar ocupar a posição como credor de reparação de dano ${ }^{22}$, mas esta ficaria submetida ao ajuizamento de ação civil indenizatória. No campo extraprocessual essa reparação também poderia ocorrer a partir do cumprimento de um acordo de não-persecução penal que preveja essa condição, ou mesmo de um acordo restaurativo fruto de práticas de autocomposição entre autor e ofendido.

Quanto à primeira forma de intervenção do ofendido no processo penal, esta se dá nas ações penais públicas condicionadas, que dependem da representação do ofendido para que a denúncia possa ser proposta pelo Ministério Público, efetivo titular do exercício do direito de ação. A relevância da preservação deste interesse do ofendido é tão grande que o art. $5^{\circ}, \S 4^{\circ}$, do Código de Processo Penal Brasileiro (CPP) veda inclusive o início da investigação do crime quando não houver sido apresentada a representação. Não obstante, antes do oferecimento da denúncia, pode o ofendido se retratar da representação (art. 25 do CPP).

Quanto \{a participação da vítima como "agente controlador", esta ocorre quando o Ministério Público (titular do exercício da ação penal pública) não houver proposto a denúncia no prazo legal, não tendo requerido o arquivamento do inquérito, poderá o ofendido ingressar com ação penal privada subsidiária da pública (art. 29 do CPP e art. 5², LIX, da Constituição), exercendo, portanto, o múnus publico da persecução penal. Todavia, além deste circunstancial protagonismo do ofendido em caso de inércia do Parquet, este poderá aditar ou repudiar a queixa ajuizada pela vítima, neste último caso podendo oferecer denúncia substitutiva, e, em

22 BARROS, Flaviane de Magalhães. A Participação da Vítima no Processo Penal. Rio de Janeiro: Lumen, 2008, p. 95, 108-115. 
todos os demais, intervir em todos os atos do processo que tenha sido iniciado pela ação subsidiária. Havendo negligência do querelante, o Ministério Público poderá retomar a ação como parte principal.

Embora a lei não especifique o que seria caracterizado como negligência, e não retire do Ministério Público a faculdade de retomar as rédeas da persecução penal, fato é que, a legislação brasileira permite, nos sobreditos termos, que o ofendido se alce à condição de substituto processual do Parquet mesmo em processos de natureza pública. 0 direito de ajuizar a ação penal privada subsidiária da pública foi inclusive alavancado à condição de direito fundamental individual e cláusula pétrea pela Constituição da República, em seu art. $5^{\circ}$, inciso LIX, como componente da inafastabilidade da jurisdição.

Outro exemplo, da vítima como agente controlador é o previsto na redação atual do art. 28, $\$ 1^{\circ}$, do CPP, que permite que o ofendido, após ser notificado da decisão do promotor de justiça pelo arquivamento do inquérito ou peças informativas, tenha o prazo de trinta dias para apresentar recurso contra tal decisão à instância revisional competente. 0 conteúdo do $\$ 1^{\circ}$ deixa claro que a contestação do arquivamento pode ser feita diretamente pela vítima ou por meio de representante legal.

Em terceiro lugar, o CPP, em seu art. 268, prevê que o ofendido, se desejar, poderá intervir em todos os atos do processo penal se admitido como assistente de acusação por decisão do magistrado que conduz o caso. 0 art. 272 determina que o Ministério Público deverá ser ouvido acerca da admissão do assistente, mas seu pronunciamento não vincula o juiz da causa, servindo apenas para formar seu convencimento.

A doutrina diverge acerca da natureza jurídica processual do assistente de acusação, havendo vertentes que o equiparam à parte propriamente dita, a mero auxiliar do titular do direito de ação, ou a substituto processual ${ }^{23}$.

Tourinho Filho expõe que o assistente de acusação tem como faculdades formular perguntas às testemunhas e ao acusado no seu interrogatório, podendo também aditar as alegações finais do Ministério Público, participar dos debates orais e arrazoar os recursos interpostos pela instituição ${ }^{24}$. A Súmula $n^{\circ} 210$ do Supremo Tribunal Federal também autoriza o assistente de acusação a recorrer das decisões judiciais ${ }^{25}$.

23 BONFIM, Edilson Mogenout. Curso de Processo Penal. 6a ed. atual. São Paulo: Atlas, 2011, p. 446.

24 TOURINHO FILHO, Fernando da Costa.Manual de processo penal. $9^{a}$ ed. rev. e atual. São Paulo: Saraiva, 2007, p. 379.

25 BRASIL Súmula n. ${ }^{\circ} 210$ do Supremo Tribunal Federal. Brasília: Supremo Tribunal Federal, 13 de dezembro de 1963. 
0 art. 598 do CPP permite que o ofendido, ou seus representantes em caso de morte ou incapacidade (nos termos do art. 31), mesmo que não habilitados como assistentes de acusação, recorram das decisões de juízes singulares ou do Tribunal do Júri se o Ministério Público não o fizer no prazo legal. Mais uma vez, a legislação brasileira mune o ofendido de ferramentas para efetivar o direito penal, como espécie de personificação da coletividade e interessado direto no caso quando o Parquet se mostrar inerte.

Nos EUA, salvo raras exceções, não há previsão legal acerca de algo semelhante a um assistente de acusação, embora seja reconhecido que o ofendido possa fornecer subsídios probatórios ao Ministério Público. No caso Burdeau vs. McDowel, a empresa Henry L. Doherty \& Co demitiu o empregado, JC MCDowell e, posteriormente, um agente da empresa assumiu o escritório que ele ocupava, revistou-o e tomou posse de documentos trancados dentro de dois cofres e uma escrivaninha; depois de revisar os documentos, alguns deles pessoais, a empresa os encaminhou para Burdeau, ao Departamento de Justiça, e eles foram utilizados como provas em um processo criminal. A Suprema Corte, entretanto, concluiu que o fato de um particular obter documentos ilegalmente e submetê-los à promotoria não representaria uma violação à quarta emenda da Constituição Federal, pois esta opõe o direito à inviolabilidade da vida e documentos privados em face do Estado ${ }^{26}$.

No Brasil, o Supremo Tribunal Federal concluiu em sentido contrário, no julgamento do Recurso Extraordinário de $\mathrm{n}^{\circ} 251445$, ao apreciar caso em que fotos furtadas de consultório profissional de um indivíduo, que comprovavam o cometimento de prática criminosa por este, foram submetidas à autoridade policial pelo autor do furto. A Corte entendeu pela inadmissibilidade de tais provas em razão da violação ao art. $5^{\circ}$, inc. XI, da Constituição, que prevê a inviolabilidade do domicílio ${ }^{27}$, ainda que em face de autoridades públicas. No presente caso, a Corte interpretou que a vedação constitucional se aplicaria também a particulares e que isso configuraria a ilicitude da prova e sua nulidade.

Com relação ao exercício da persecução penal subsidiária pelo ofendido, no caso de inércia do Parquet, a Suprema Corte dos EUA já decidiu pela sua impossibilidade, por exemplo,

26 PALMER, John Gregory. Burdeau v. McDowell, 256 U.S. 465 (1921). 2012. Disponível em: http: / / uscivilliberties.org/cases/3261-burdeau-v-mcdowell-256-us-465-1921.html. Acesso em 28/12/2018. 27 BRASIL. Recurso Extraordinário 251445 GO. Supremo Tribunal Federal: Relator Min. Celso de Mello, 21 de junho de 2000. Em: https://stf.jusbrasil.com.br/jurisprudencia/14825705/recurso-extraordinario-re251445-go-stf. Acesso em 28 de dez. de 2018. 

PENAL: UMA ANÁLISE COMPARATIVA ENTRE O DIREITO BRASILEIRO E O NORTE AMERICANO

nos casos Linda R. S. vs. Richard $D .{ }^{28}$ e Leeke v. Timmerman ${ }^{29}$, ressaltando a competência exclusiva do Ministério Público para promover ações penais em casos de crimes federais.

A mesma regra se aplica aos crimes estaduais, mas há exceções, como no Estado da Virgínia, no qual se admite a figura do private prosecutor, tanto na sua composição pura, assim como assistente do public prosecutor ${ }^{30}$. Os estados do Alabama, Geórgia, Indiana, Ohio, Pensilvânia, Tennessee, Vermont, West Virginia, e Wisconsin, por sua vez, também permitem que advogados particulares patrocinem os interesses dos ofendidos, ou pessoas com comprovado interesse, em causas penais, sempre na condição de assistentes de acusação ${ }^{31}$.

Todas as supracitadas intervenções processuais do ofendido são, entretanto, indiretas, pois, mesmo norteadas por seus interesses pessoais, restam efetivadas por advogados, uma vez que o ofendido em si, caso não se enquadre na referida categoria, carece de capacidade postulatória perante o juízo.

Seja como for, o comportamento do ofendido é decisivo para a ocorrência ou não do processo penal, especialmente porque, na maioria dos casos, quem aciona o Estado para iniciar as investigações que poderão culminar na persecução penal é ele ${ }^{32}$. 0 ofendido pode optar por não testemunhar, ou alterar sua versão dos fatos e assim comprometer o trabalho da acusação, ou pode contribuir com a coleta de evidências para atestar a existência da ofensa penal ${ }^{33}$.

\footnotetext{
${ }^{28}$ Neste caso, a apelante pleiteou a prisão do genitor de seu filho, com base em dispositivo penal, pelo fato desse não fornecer apoio financeiro ao menor, mas a Corte entendeu que um cidadão privado carece de interesse judicialmente cognoscível para promover a persecução penal de outro, sendo tal incumbência exclusiva do Ministério Público. Em: LAW SCHOOL CASE BRIEFS. Linda R. S. v. Richard D. case Summary. Jan, 2013. Disponível em: http://www.lawschoolcasebriefs.net/2013/01/linda-rs-v-richard-d-casesummary.html. Acesso em 28 de dez. de 2018.

29 Neste caso, os demandantes eram presidiários que alegaram ser desnecessariamente agredidos por autoridades policiais durante uma revolta na prisão e pleitearam perante o magistrado competente a expedição de mandados de prisão contra seus agressores. A expedição foi negada e então os requerentes ingressaram com uma ação contra as autoridades que denegaram o pedido, alegando que estas haviam conspirado de má-fé para obstar a acusação dos guardas. A questão chegou à Suprema Corte que concluiu pela ilegitimidade passiva dos requerentes para pleitearem a expedição dos mandados e que mesmo a expedição destes não significaria a instauração de um processo penal, pois a persecução penal é só poderia ser realizada pelo Ministério Público. Em: ESTADOS UNIDOS. Leeke v. Timmerman, 454 EUA 83 (1981). Suprema Corte: 1981. Disponível em: https://supreme.justia.com/cases/federal/us/454/83/. Acesso dia 28 de dez. de 2018.

${ }^{30}$ NICHOLS, MATTHEW. No One Can Serve Two Masters: Arguments Against Private Prosecutors. Capital Defense Journal: Volume 13, Issue 2, p. 279-305, Spring -3-1-2001 p. 279-281.

31 NICHOLS, MATTHEW. No One Can Serve Two Masters: Arguments Against Private Prosecutors. Capital Defense Journal: Volume 13, Issue 2, p. 279-305, Spring -3-1-2001 p. 282.

32 DUBBER, Markus Dirk. The Victim in American Penal Law: A Systematc Overview. Buffalo Criminal Law Review: Victim in Penal Law. Bufflalo: Oct. 21, vol. 3:3, p. 3-31, 1999, p. 16-17.

33 DUBBER, Markus Dirk. The Victim in American Penal Law: A Systematc Overview. Buffalo Criminal Law Review: Victim in Penal Law. Bufflalo: Oct. 21, vol. 3:3, p. 3-31, 1999, p. 17, 21.
} 
No Brasil, caso a autoridade policial se recuse a iniciar investigações de conduta criminosa requeridas pelo ofendido, a este é assegurado interpor contra a decisão de indeferimento recurso inominado endereçado ao chefe de polícia (art. $5, \S 2^{\circ}, \mathrm{CPP}$ ), ou requer providências diretamente ao Ministério Público. 0 delegado não é obrigado a instaurar procedimento investigatório, mas tem a obrigação de verificar a plausibilidade do contido na notitia criminis $^{34}$. 0 art. 14 do CPP assegura ao ofendido o direito, inclusive de requerer diligências à autoridade policial durante a investigação. Como se trata de seara administrativa, neste campo, o ofendido pode atuar diretamente, sem intermediação de um advogado.

Em se tratando das possíveis intervenções direitas do ofendido no processo, ou durante a fase preparatória para este, importante ressaltar que em alguns estados, como Alabama e Arizona, tratando-se de casos mais graves, como homicídio e estupro, os promotores consultam a vítima antes de denunciar o suspeito ${ }^{35}$.

O direito de conferência entre promotor e ofendido para tratar dos termos da denúncia ou de sua disposição também é garantido por constituições estaduais, tais como a Constituição do Alasca (art. I, §24), do Arizona (art. II, §2.1), de Idaho (art. I, § 22(5)), de Illinois (art. I, §8.1 (a) (3)), de Michigan (art. I, §24 (i)), etc ${ }^{36}$.

Essa consulta ao ofendido pode servir não apenas para embasar a denúncia a partir da melhor precisão dos fatos, ou averiguar que providência ele espera do Estado em relação ao que The foi feito, mas igualmente possibilitar que o processo seja evitado a partir de um acordo celebrado entre Ministério Público e Ofensor, acordo este que poderá ser direcionado de forma diversa pela promotoria a depender das informações providenciadas pelo sujeito.

Nos EUA, quase a totalidade dos casos criminais são resolvidos através do plea bargaining (negociação entre suspeito e promotoria) e os movimentos das vítimas, portanto, pleiteiam a participação do ofendido durante o procedimento de negociação ${ }^{37}$.

A CVRA determina que a vítima deve ser ouvida pelo promotor em procedimentos públicos envolvendo pleas, mas esta não tem o direito de obstar a atividade da promotoria (é uma oitiva consultiva) ${ }^{38}$.

\footnotetext{
${ }^{34}$ BRASILEIRO, Renato. Manual de Processo Penal. $4^{\text {a }}$ ed. Salvador: Juspodvim, 2016, p. 194.

35 DUBBER, Markus Dirk. The Victim in American Penal Law: A Systematc Overview. Buffalo Criminal Law Review: Victim in Penal Law. Bufflalo: Oct. 21, vol. 3:3, p. 3-31, 1999, p. 17.

36 BELOOF, Douglas E. The Third Wave of Crime Victim's Rights: Standing, Remedy, and Review. BUE Law Review. Article 1, Issue 2, p. 256- 365, 2005, p. 266.

37 DUBBER, Markus Dirk. The Victim in American Penal Law: A Systematc Overview. Buffalo Criminal Law Review: Victim in Penal Law. Bufflalo: Oct. 21, vol. 3:3, p. 3-31, 1999, p. 22.
} 
Na prática, todavia, a condução do plea bargaining é feita de modo discricionário pela promotoria, sem nenhum controle externo ou transparência, na crença de que as negociações estão sendo conduzidas para melhor atender ao interesse público, afinal essa fase pré-processual não é regulamentada por lei, ficando sua realização vinculada à política adotada pelo gabinete do promotor responsável ${ }^{39}$. Tratam-se de negociações ad hoc, privadas e sem transparência ${ }^{40}$

Um dos grandes problemas para os ofendidos é que, a fim de que as negociações resultem em um acordo, a promotoria pode omitir fatos relevantes do caso penal, relatando uma situação menos gravosa para garantir a confissão e cessão de sólido material probatório da parte do acusado em relação a crimes mais leves do que poderia constar na acusação, assim um crime doloso pode se tornar culposo, um crime qualificado pode se tornar simples, etc ${ }^{41}$. Dessa maneira, as histórias vivenciadas pelos ofendidos são moldadas pelo sistema legal no plea bargaining, e, salvo a sua intervenção nas conferências, não há nenhum remédio processual que eles podem utilizar para reverter a decisão da promotoria ${ }^{42}$.

O Victims Charter Act de 2006 definiu obrigações estatutárias aos promotores de informar aos ofendidos quando o plea bargaining resulta em redução do número de acusações ou de penas que poderiam ser promovidas, porém o diploma veda o ingresso de ações civis de indenização caso isso seja desrespeitado pelo agente público ${ }^{43}$.

Apesar de não possuir força coercitiva, o Victims Charter Act garantiu que as vítimas recebessem mais informações, embora haja críticas no sentido de que ele muitas vezes provoca certa confusão acerca de quem o Ministério Público efetivamente representa, sem mencionar

\footnotetext{
${ }^{38}$ AARONSON, David E. New Rights and Remedies: The Federal Crime Victims Rights Act of 2004. Pace Law Review, Symposium Victims and The Criminal Justice System, Issue 4, v. 28, p. 623-682, Summer 2008, p. 656.

${ }^{39}$ FLYNN, Asher. Bargaining with justice: victims, plea bargaining and the Victims' Charter act 2006 (VIC). Monash University Law Review, Vol 37, n. 3, p. 73- 96, 2011, p. 75, 80.

40 O' HEAR, Michael M. Plea Bargaining and Victims: from consultation to guidelines. Marquette Law Review. Volume 91, Issue 1 Symposium: Dispute Resolution in Criminal Law, Article 14, 323-347, 2007, p. 324.

${ }^{41}$ FLYNN, Asher. Bargaining with justice: victims, plea bargaining and the Victims' Charter act 2006 (VIC). Monash University Law Review, Vol 37, n. 3, p. 73- 96, 2011, p. 83.

${ }^{42}$ FLYNN, Asher. Bargaining with justice: victims, plea bargaining and the Victims' Charter act 2006 (VIC). Monash University Law Review, Vol 37, n. 3, p. 73- 96, 2011, p. 85.

${ }^{43}$ FLYNN, Asher. Bargaining with justice: victims, plea bargaining and the Victims' Charter act 2006 (VIC). Monash University Law Review, Vol 37, n. 3, p. 73- 96, 2011, p. 89.
} 
que ela aumenta consideravelmente a carga de trabalho do gabinete ${ }^{44}$. 0 Ato também determina que o ofendido receba explicações acerca das razões da decisão do promotor de justiça ${ }^{45}$.

Tais disposições, ainda que não cogente, são fruto das pressões dos movimentos das vítimas para a implementação de uma política de accountability em sede do plea bargaining ${ }^{46}$.

No Brasil, todavia, o princípio da oportunidade da persecução penal não é tratado como nos Estados Unidos. Em que pese o art. 28 do CPP permita que o arquivamento do inquérito policial seja feito pelo Ministério Público, tal decisão ainda é previamente submetida à apreciação judicial, conforme redação antiga do referido dispositivo, em razão de decisão monocrática liminar do Supremo Tribunal Federal, proferida em sede das Ação Direta de Inconstitucionalidade $\mathrm{n}^{\circ}$ 6.305. Portanto, ainda vigora, como regra, o entendimento sobre a validade do princípio da obrigatoriedade da persecução penal de crimes pelo Parquet quando cumpridos os requisitos de admissibilidade da ação penal.

Afrânio Silva Jardim observa que a obrigatoriedade provém do princípio da oficialidade, pois a aplicação do direito penal depende da atuação dos órgãos públicos e ressalta que se o legislador incriminou uma conduta, dando relevância social ao bem jurídico afetado ou posto em risco por ela, não pode o membro do MP afirmar que a ação delituosa não possui relevância, ou que o interesse público seria atendido através da sua inércia ${ }^{47}$.

Apesar da obrigatoriedade ainda ser entendida como vigente, baseando-se na ratio do plea bargaining, o Conselho Nacional do Ministério Público (CNMP) aprovou a Resolução n 181 de 2017, que previu, em sede do Procedimento Investigatório Criminal e de inquéritos a ele vinculados, não sendo o caso de arquivamento, a possibilidade de proposição pelo Parquet do “Acordo de Não-Persecução Penal” (ANPP) ao investigado nas condições ora regulamentadas pelo CPP em razão da Lei n 13.964 de $2019^{48}$.

44 FLYNN, Asher. Bargaining with justice: victims, plea bargaining and the Victims' Charter act 2006 (VIC). Monash University Law Review, Vol 37, n. 3, p. 73- 96, 2011, p. 91.

45 FLYNN, Asher. Bargaining with justice: victims, plea bargaining and the Victims' Charter act 2006 (VIC). Monash University Law Review, Vol 37, n. 3, p. 73- 96, 2011, p. 95.

46 O' HEAR, Michael M. Plea Bargaining and Victims: from consultation to guidelines. Marquette Law Review. Volume 91, Issue 1 Symposium: Dispute Resolution in Criminal Law, Article 14, 323-347, 2007, p. 324.

47 JARDIM, Afrânio Silva. Ação Penal Pública: Princípio da Obrigatoriedade. Rio de Janeiro: Forense, 1988, p. 43,45 .

48 Nesse sentido, podemos citar::(i) a confissão de autoria de delito com pena mínima inferior a 4 anos, praticado sem violência ou grave ameaça; (ii) não ser cabível transação penal; (iii) não ser o investigado reincidente e não haver indícios de práticas criminosas habituais que não sejam "insignificantes" (a lei não esclarece esse conceito), (iv) não pode o investigado ter sido beneficiado nos 5 anos anteriores ao cometimento da infração, por ANPP, transação penal ou suspensão condicional do processo; e (v) o crime 
Diferentemente dos ditos casos nos EUA em que se prevê a consulta ou a possibilidade do ofendido de se reunir com o promotor, a Lei não prevê hipóteses de intervenção direta desse para fins de celebração do ANPP, mas apenas o dever do promotor de comunica-lo quando da sua homologação ou descumprimento (art. 28-A, \$9) e o escopo reparativo do acordo (art. 28-A, inciso I). Assim, tanto nos EUA quanto no Brasil a independência entre o titular do direito de ação e a vontade do ofendido é preservada, mas no Brasil nada impede que o ofendido se reúna com o promotor ou seja notificado para comparecer à promotoria a fim de discutir os termos da proposta do acordo que melhor considere as suas necessidades.

Outra forma significativa de participação direta da vítima nos EUA, esta no processo penal propriamente dito, é através da declaração de impacto, que consiste em uma manifestação da vítima, ou de seus familiares (a depender da extensão do conceito de ofendido oferecido pela lei aplicável) acerca dos efeitos do crime em sua vida perante o juiz e o júri, após a condenação do acusado mas momentos antes do juiz determinar a pena a ser aplicada ${ }^{49}$.

Via de regra, as vítimas realizam essa declaração com o intuito de instigar a estipulação de uma pena severa, de modo tal que tradicionalmente ela não se coaduna com oitava emenda constitucional, que trata da proporcionalidade da pena, ou com a décima quarta ementa, que trata do devido processo legal e pressupõe que todos os fatos aventados durante o processo tenham sido objeto de comprovação e contestação ${ }^{50}$. O que mitiga, em tese, as potenciais violações da declaração de impacto às referidas emendas é o fato do juiz ter a faculdade de apenas considerar elementos que tenham sido cabalmente comprovados durante a instrução, para fins de aumentar a pena ${ }^{51}$.

Entretanto, a legislação dos Estados Unidos vem avançando em favor das vítimas nos últimos anos, como pode ser atestado pela promulgação do "Victim and Witness Protection Act" (1982), do "Victims of Crime Act" (1984), do "Victims Rights and Restitution Act" (1990); e do "Victim's Bill of Rights" (1994), além do que, atualmente a vítima tem o direito de se

não pode ter sido praticado no âmbito de violência doméstica ou familiar, ou contra a mulher por razões da condição de sexo feminino. Em: BRASIL. Lei n 13.964, de 2019. Brasília: Congresso Nacional, 2019.

49 STEVENS, Mark Victim Impact Statements Considered in Sentencing. Berkeley Journal of Criminal Law. Volume 2, Issue 1, article 3, p. 1-13, 2000, p. 1.

50 STEVENS, Mark Victim Impact Statements Considered in Sentencing. Berkeley Journal of Criminal Law. Volume 2, Issue 1, article 3, p. 1-13, 2000, p. 3.

${ }^{51}$ FLYNN, Asher. Bargaining with justice: victims, plea bargaining and the Victims' Charter act 2006 (VIC). Monash University Law Review, Vol 37, n. 3, p. 73- 96, 2011, p. 84. 
pronunciar no sentenciamento em todos os 50 estados da Federação ${ }^{52}$, afinal seria suicídio eleitoral opor-se às iniciativas de direitos desse grupo ${ }^{53}$.

O Código Penal do Arizona, além de prever o direito ao victims impact statement, especificou que tipo de informações poderiam ser compreendidas por ele, como a explicação sobre a natureza dos danos físicos e psicológicos sofridos, sobre a extensão de danos pecuniários e uma opinião sobre a necessidade e medida da restituição esperada ${ }^{54}$.

Em relação aos casos nos quais havia possibilidade de aplicação de pena capital, em um primeiro momento a Suprema Corte dos Estados Unidos, nos casos Booth vs Maryland (1987) and South Carolina vs. Gathers (1989), concluiu pela inconstitucionalidade da previsão da declaração de impacto nos estatutos que vinham sendo publicados, com base na Oitava Emenda, que trata da vedação a pena cruel. Entretanto, em 1991, no caso Payne v. Tennessee, a Corte voltou atrás apresentando como alguns de seus fundamentos que o stare decisis não é um comando inexorável, que o princípio da punição deve se fazer presente nos casos de crimes brutais, que o réu teve a oportunidade de apresentar provas mitigadoras durante a instrução e que o Ministério Público tem direito de apresentar provas sobre a extensão do dano causado à vítima ${ }^{55}$.

Nota-se então que, mesmo direcionado, em algumas legislações, e, supostamente com limitados efeitos práticos, uma vez que aquilo que não tenha o devido subsídio probatório não poderá (ao menos formalmente) servir de motivação para o aumento da pena, o discurso do ofendido através da declaração de impacto diz respeito a uma intervenção pessoal da vítima no processo penal norte-americano que tem o potencial de influenciar o entendimento do juízo.

O direito brasileiro, ao seu turno, não assegura participações diretas que abarquem questões mais simbólicas para o ofendido, como a declaração de impacto, embora nada impeça que o magistrado autorize a vítima a narrar mais livremente os impactos do crime em sua vida, o que pode repercutir, se comprovado, na dosimetria da pena, especialmente no que toca à circunstância judicial referente às "consequências do crime” (art. 59, CP).

Tem-se, contudo, que mesmo quando da manifestação através da declaração de impacto caso o ofendido deseje realiza-la e expressar seus sentimentos e as consequências do delito, ele

52 BELOOF, Douglas E. Constitutional Implications of Crime Victims as Participants. Cornell Law Review,Volume 88, Issue 2, article 2, p. 282-305, January 2003, p.286.

53 STEVENS, Mark Victim Impact Statements Considered in Sentencing. Berkeley Journal of Criminal Law. Volume 2, Issue 1, article 3, p. 1-13, 2000, p. 3 - 4.

54 Alínea c da seção 13-4410. Em: ARIZONA. CRIMINAL CODE OF ARIZONA (Title 13). Congresso Estadual do Arizona. Disponível em: https://www.azleg.gov/arsDetail/?title=13. Acesso em 29 de dezembro de 2018. 55 STEVENS, Mark Victim Impact Statements Considered in Sentencing. Berkeley Journal of Criminal Law. Volume 2, Issue 1, article 3, p. 1-13, 2000, p. 6,9. 
continua operando em grande medida como um objeto de extração probatória para o sistema penal, afinal, o objetivo primordial dessa declaração, não raro direcionada (pela lei ou pelo juiz), é justamente afetar a natureza ou a dosimetria da pena estipulada após a condenação.

Ao assistir à acusação, atuar como substituto processual na ação penal privada subsidiária da pública, ou ainda quando profere a declaração de impacto, ou consulta com o promotor nos casos de plea bargaining, o ofendido, mesmo superando a posição de mero espectador, ainda é tratado como um braço adicional do jus puniendi e um cointeressado diretamente na punição do ofensor. Observa-se então que os sistemas penais norte-americano e brasileiro parecem ainda pressupor uma tendência vingativa no caráter da vítima e, quando the permitem intervenções, dão maior enfoque no seu papel de auxiliar estatal da persecução penal.

\section{OS DIREITOS DAS VÍTIMAS PARA ALÉM DO PROCESSO PENAL}

Além de inicialmente prever o ANPP, a Resolução 181 do CNMP dedicou um capítulo aos “direitos das vítimas" no Procedimento Investigatório Criminal, que também são extensíveis aos seus familiares, determinando que o promotor de justiça esclareça a vítima sobre seus direitos materiais e processuais e tome medidas necessárias para preservá-los, favorecendo a reparação dos danos sofridos e preservando a sua intimidade, vida privada, honra e imagem. Essa última previsão espelha o previsto no art. 201, $\$ 6^{\circ}$, do CPP, que, em sede processual, obriga o magistrado a adotar providências similares, podendo determinar o segredo de justiça em relação aos dados da vítima e seus depoimentos.

A resolução também determina que o promotor de justiça garanta à vítima a possibilidade de prestar declarações de modo espontâneo, sugerir diligências, indicar meios de prova e deduzir alegações. Outra previsão foi a determinação, no $\$ 4^{\circ}$ do art. 17 , quanto ao encaminhamento da vítima ou outras pessoas atingidas pelo delito à rede de assistência multidisciplinar para atendimento (psicossocial, de assistência jurídica e de saúde). Esses atendimentos, se não forem públicos ou gratuitos, deverão ser custeados pelo ofensor e subsidiariamente, pelo Estado. Tal determinação se espelhou no conteúdo do art. 201 , §5 , do CPP, mas resolução inovou ao dispor que o encaminhamento é um dever. 
Fica claro então que os direitos dos ofendidos não precisam ser funcionais ao processo ou à hipótese da acusação, devendo ser considerados em sua dimensão humanitária ${ }^{56}$. Permanece, de todo modo, tensão latente em relação aos direitos do acusado: no caso Morris vs. Slappy, por exemplo, a Suprema Corte dos Estados Unidos entendeu que os direitos do acusado não devem ser efetivados de maneira que desnecessariamente lesem o ofendido, o que ocorre, por exemplo, quando a corte impede a declaração de impacto, ou a recomendação de sentença ${ }^{57}$.

Há situações em que garantir o cumprimento dos direitos da vítima tende a mitigar o direito do acusado, como no caso do direito dela ser informada com razoabilidade de tempo acerca dos atos processuais, conforme apregoa a CVRA, vs. a Rule 5(a) do Federal Rules of Criminal Procedure, que assegura ao acusado o direito de ser levado sem atraso até o juiz. Nesse sentido, se prevalecer o direito da vítima, admitir-se-ia o atraso na apresentação de um acusado preso ao juiz, em razão da necessidade de prévia notificação do ofendido desse ato ${ }^{58}$.

Ocorre que, ao contrário dos direitos dos acusados, os direitos dos ofendidos raramente são acompanhados por previsões legais assegurando remédios processuais específicos para sua garantia em caso de violação ${ }^{59}$. Evidentemente, o acusado, em vias de ser penalizado, está em uma posição de sofrer uma violência aos seus direitos muito maior do que o ofendido, mas é inegável que a positivação de direitos sem a previsão dos meios para pleiteá-los enfraquece fortemente seu caráter mandamental. Ora, mesmo na disposição do CPP acerca do recurso inominado em procedimento administrativo endereçado ao chefe de polícia, na qual este possui certa discricionariedade, a previsão do remédio por si só enaltece o direito do ofendido de provocar o início de investigações.

O fato é que a única garantia de que os direitos dos ofendidos serão cumpridos é a existência de um caráter mandamental que impeça o Estado de adotar a discricionariedade em sua observação $0^{60}$. A configuração deste caráter se dá através da linguagem normativa que não adota termos permissivos para sua inobservância (como: “poderá”, "se conveniente”, "se

${ }^{56}$ BELOOF, Douglas E. The Third Wave of Crime Victim's Rights: Standing, Remedy, and Review. BUE Law Review. Article 1, Issue 2, p. 256- 365, 2005, p. 307.

${ }^{57}$ BELOOF, Douglas E. Constitutional Implications of Crime Victims as Participants. Cornell Law Review, Volume 88, Issue 2, article 2, p. 282-305, January 2003, p. 295.

${ }^{58}$ AARONSON, David E. New Rights and Remedies: The Federal Crime Victims Rights Act of 2004. Pace Law Review, Symposium Victims and The Criminal Justice System, Issue 4, v. 28, p. 623-682, Summer 2008, p.635-647.

${ }^{59}$ BELOOF, Douglas E. The Third Wave of Crime Victim's Rights: Standing, Remedy, and Review. BUE Law Review. Article 1, Issue 2, p. 256- 365, 2005, p. 275.

${ }^{60}$ AARONSON, David E. New Rights and Remedies: The Federal Crime Victims Rights Act of 2004. Pace Law Review, Symposium Victims and The Criminal Justice System, Issue 4, v. 28, p. 623-682, Summer 2008, p. 644. 
oportuno", etc.) e define de modo preciso a extensão do direito e a previsão de remédios para sua concretização em caso de violação. A imprecisão da descrição normativa de certos direitos aumenta a discricionariedade estatal acerca de seu significado e extensão e, para Bellof, tornaos direitos ilusórios, afinal, mesmo que eventualmente se conte com remédios processuais, a sua efetivação fica ao sabor do intérprete ${ }^{61}$.

Por exemplo, o $\$ 5^{\circ}$ do art. 201 do CPP permite o encaminhamento do ofendido a atendimento multidisciplinar "se o juiz entender necessário". 0 \$6, por sua vez, possui uma linguagem de cunho mandamental, apontando que o juiz "tomará" providências necessárias para preservar a imagem, a honra e a intimidade desse, mas não especifica quais poderiam ser tais medidas. Outro exemplo é o art. I, \$22 (6) da Constituição de Idaho, que estipula que a vítima somente pode se manifestar processualmente quando manifestamente injustiçada ${ }^{62}$. A constituição do Missouri prevê, a princípio, o direito mandamental da vítima ser informada e ouvida, mas cria uma exceção que compromete tal mandamento, ao estipular: "a menos que, por determinação da corte, os interesses da justiça sejam outros” (art. I, §32 (2) $)^{63}$.

Os direitos genéricos dos ofendidos seriam aqueles relativos ao tratamento com respeito, dignidade, e justiça, previstos, só em 2005, em pelo menos 19 constituições estaduais norteamericanas $^{64}$. Os direitos específicos são aqueles que estipulam a observância de medidas determinadas, como no $\$ 2^{\circ}$ do art. 201 do CPP, que trata do dever de se comunicar o ofendido dos atos processuais relativos às decisões que mantenham ou modifiquem e a prisão ou soltura do acusado. Outro direito específico previsto na Resolução nº 253 de 2018 do CNJ é o dever de orientação do ofendido sobre as etapas do inquérito policial, de eventual processo e o seu direito de consultar ou de obter cópias dos autos (art. $3^{\circ}$, inciso II) ${ }^{65}$.

Esses direitos podem alterar regras processuais em favor das vítimas com mais frequência do que os genéricos, fazendo frente aos direitos dos acusados, como ocorreu em State v. Lamar,

61 BELOOF, Douglas E. The Third Wave of Crime Victim's Rights: Standing, Remedy, and Review. BUE Law Review. Article 1, Issue 2, p. 256- 365, 2005, p. 297.

62 BELOOF, Douglas E. The Third Wave of Crime Victim's Rights: Standing, Remedy, and Review. BUE Law Review. Article 1, Issue 2, p. 256- 365, 2005, p. 296.

63 BELOOF, Douglas E. The Third Wave of Crime Victim's Rights: Standing, Remedy, and Review. BUE Law Review. Article 1, Issue 2, p. 256- 365, 2005, p. 295-296.

64 BELOOF, Douglas E. The Third Wave of Crime Victim's Rights: Standing, Remedy, and Review. BUE Law Review. Article 1, Issue 2, p. 256- 365, 2005, p. 262.

65 BRASIL. Resolução nº 253 de 04 de setembro de 2018. Brasília: Conselho Nacional de Justiça, 2018. 
julgado no Arizona, no qual o direito da vítima a um julgamento célere foi sopesado com o direito do acusado de se preparar para o julgamento ${ }^{66}$.

No Brasil, embora existam previsões acerca de direitos genéricos e que concedam ao juiz grande discricionariedade para observar tais direitos, uma série de normas dos EUA que preveem direitos às vítimas vedam a possibilidade de ingresso de ações indenizatórias caso haja o seu desrespeito e, por vezes, impedem o uso de remédios processuais para lidar com violações.

Em United States v. McVeigh a Corte de Apelação da Décima Circunscrição negou o writ of mandamus impetrado pelas vítimas, baseado no direito de estarem presentes nos atos públicos do julgamento, afirmando que tal direito não podia ser garantido pela referida ação constitucional, ou seja, afirmou-se, na prática, que se trata de um direito de efetivação discricionária diante do silêncio da lei acerca do remédio processual cabível para sua defesa ${ }^{67}$.

A Constituição de Nebraska é mais específica, mas não confere plenitude aos direitos das vítimas, pois determina em seu art. $1^{\circ}$, 28 , que não haverá remédios processuais para se pleitear a obediência a tais direitos, salvo previsão especifica na legislação estadual ${ }^{68}$. A Constituição de Idaho prevê, em seu art. $1^{\circ}$, $\$ 22$ (10), que os direitos das vítimas são de eficácia plena, podendo ser expandidos através de previsão infraconstitucional ${ }^{69}$. A Constituição da Carolina do Sul, em sentido contrário, dispõe que o remédio processual para pleitear a obediência dos direitos das vítimas é o writ of mandamus ${ }^{70}$. A Constituição do Kansas, ressalta que eventual constrição aos direitos dos ofendidos não dá causa para ações indenizatórias contra o Estado (art. 15, §15, alínea b) ${ }^{71}$, linha também seguida na legislação federal pela CVRA, a qual veda o reconhecimento de nulidade dos julgamentos em caso de violações a estes direitos ${ }^{72}$.

A CVRA, entretanto, garante expressamente o uso de remédios processuais no caso da violação dos direitos das vítimas, estipulando o direito de apelo toda vez que estes forem

${ }^{66}$ BELOOF, Douglas E. The Third Wave of Crime Victim's Rights: Standing, Remedy, and Review. BUE Law Review. Article 1, Issue 2, p. 256- 365, 2005, p. 269.

${ }^{67}$ BELOOF, Douglas E. The Third Wave of Crime Victim's Rights: Standing, Remedy, and Review. BUE Law Review. Article 1, Issue 2, p. 256- 365, 2005, p. 279.

${ }^{68}$ BELOOF, Douglas E. The Third Wave of Crime Victim's Rights: Standing, Remedy, and Review. BUE Law Review. Article 1, Issue 2, p. 256- 365, 2005, p. 286.

${ }^{69}$ BELOOF, Douglas E. The Third Wave of Crime Victim's Rights: Standing, Remedy, and Review. BUE Law Review. Article 1, Issue 2, p. 256- 365, 2005, p. 286.

${ }^{70}$ BELOOF, Douglas E. The Third Wave of Crime Victim's Rights: Standing, Remedy, and Review. BUE Law Review. Article 1, Issue 2, p. 256- 365, 2005, p. 341.

${ }^{71}$ BELOOF, Douglas E. The Third Wave of Crime Victim's Rights: Standing, Remedy, and Review. BUE Law Review. Article 1, Issue 2, p. 256- 365, 2005, p. 281.

72 AARONSON, David E. New Rights and Remedies: The Federal Crime Victims Rights Act of 2004. Pace Law Review, Symposium Victims and The Criminal Justice System, Issue 4, v. 28, p. 623-682, Summer 2008, p.666-667. 
desrespeitados e ainda determina que a corte de apelação deve ouvir a vítima e decidir a questão em setenta e duas horas depois do envio do apelo, podendo o processo em instância inferior ficar suspenso por até cinco dias até a publicação da decisão da corte de apelação, a qual, se denegatória, deverá listar os motivos para tanto ${ }^{73}$.

No Brasil não há previsão expressa de remédios processuais no caso de violação dos direitos das vítimas, mas considerando que estas não são parte no processo penal e que alguns de seus direitos possuem cunho mandamental, a solução jurídica para o ofendido assegurar a observância destes na esfera processual penal poderia ser através da impetração de mandado de segurança. Não há também vedação ao ajuizamento de ações indenizatórias contra o Estado no caso de violação desses direitos.

Quanto a outros direitos do ofendido nos EUA, o Victims Restitution Act de 1990, foi o mais significativo ato legislativo até a atual CVRA, pois garantiu aos ofendidos, na esfera federal, (i) o direito a um tratamento com justiça e respeito, respeitando-se sua dignidade e privacidade, (ii) o direito à proteção razoável contra o acusado, (iii) o direito de ser notificado dos procedimentos relativos à ofensa, a menos que a corte considere que isso afete o seu testemunho, (iv) o direito à restituição e (v) o direito de receber informações sobre a acusação, aplicação da pena, cumprimento da pena e soltura do acusado ${ }^{74}$.

O Victim Rights Clarification Act de 1997, previu o direito do ofendido de ingresso à corte e o direito de assistir ao julgamento, mesmo se fosse prestar depoimento no dia, salvo se a legislação estadual prever o contrário ${ }^{75}$. As previsões expressas neste sentido e a possibilidade da vítima diretamente expressar na sua declaração de impacto o montante que julga justo receber de indenização, refletem a importância que os EUA reconhecem ao direito de reparação em virtude dos danos causados pelo crime.

No Brasil, o art. 387, inciso IV, do CPP define que, ao proferir sentença condenatória, o juiz fixará valor mínimo para reparação dos danos causados pela infração, considerando os prejuízos sofridos pelo ofendido. O conteúdo desse dispositivo, no entanto, gera controvérsia

73 AARONSON, David E. New Rights and Remedies: The Federal Crime Victims Rights Act of 2004. Pace Law Review, Symposium Victims and The Criminal Justice System, Issue 4, v. 28, p. 623-682, Summer 2008, p.664-665.

74 AARONSON, David E. New Rights and Remedies: The Federal Crime Victims Rights Act of 2004. Pace Law Review, Symposium Victims and The Criminal Justice System, Issue 4, v. 28, p. 623-682, Summer 2008, p. 628.

75 AARONSON, David E. New Rights and Remedies: The Federal Crime Victims Rights Act of 2004. Pace Law Review, Symposium Victims and The Criminal Justice System, Issue 4, v. 28, p. 623-682, Summer 2008, p. 629. 
quando o pedido de indenização não é feito na peça acusatória, pois, ao conferir uma indenização de ofício, há violação ao princípio do contraditório.

Ainda sobre o tema da indenização, o art. 63 do CPP assegura que a sentença penal condenatória pode ser utilizada como título executivo na seara cível para fins de ingresso com ações indenizatórias e o art. 68, atento às limitações das classes sociais menos abastadas, prevê que quando a vítima for pobre (sem, entretanto, oferecer critérios para o que é pobreza) o MP ou, mais corretamente, a Defensoria Pública promoverá a ação indenizatória de reparação ${ }^{76}$. 0 art. 127 do mesmo diploma concede ao ofendido a faculdade de requerer ao juízo penal o sequestro de bens do acusado para que esse possa ter acesso mais facilmente aos valores a serem ressarcidos, enquanto o art. 140 estende as garantias do ressarcimento do dano também às despesas processuais, ressaltando, todavia, a prioridade do ressarcimento do dano.

Por mais que o direito penal não tenha um escopo reparatório e mesmo com as abstrações jurídicas relativas ao direcionamento discursivo da ofensa em face do Estado e de bens jurídicos, percebe-se que ambos os países, com seus respectivos sistemas jurídicos diversos, reconhecem ao ofendido direitos que também destoam da lógica tradicional do processo penal e reconhecem o status de sujeito de direitos da vítima no âmbito processual. É comum se afirmar que o processo penal visa a "preservar a paz social” pela "harmonização dos conflitos". A rigor, trata-se de uma finalidade declarada distante do conteúdo material de sua concretização cotidiana. Mas a reparação de danos, como ato institucional comunicativo de reprovabilidade, sem ser pena, tem um potencial a ser ainda muito explorado, sobretudo pelas práticas restaurativas, por meio das quais tanto ofendido como autor da ofensa podem atuar ativamente e cooperativamente na construção de uma resposta ao caso penal.

No âmbito judicial, o acesso das vítimas às práticas restaurativas é regulamentado pela Resolução $\mathrm{n}^{\circ} 225$ de 2016 do CNJ, que ressalta a importância da reparação de danos, responsabilização e atendimento a necessidades como seu enfoque, e adota dentre as linhas programáticas de implementação de programas restaurativos, o acesso universal à via restaurativa e o caráter sistêmico, buscando integrar tais programas à políticas públicas e redes de apoiam que fortaleçam os direitos das vítimas numa perspectiva restaurativa.

Todavia, as intervenções processuais da vítima, como visto, são ainda voltadas principalmente à efetivação ou incremento da punição. Por esse motivo, a fim de se evitar o uso da vítima como instrumento do Sistema Penal e buscar a efetivação da "paz social” para além da

760 art. 68 do CPP é considerando caso de "inconstitucionalidade progressiva" sobre o legitimado para propor tal ação (STF, RE 135.328/SP, RTJ 177/879). 
aplicação da imposição da pena, é fundamental que o Sistema de Justiça invista na efetivação de práticas que abarquem a dimensão humana do conflito e possibilitem a participação ativa da vítima por via de procedimentos e práticas de construção de respostas que tragam esclarecimentos, considerem seus sentimentos e oportunizem não só um espaço de narrativa como também a reparação dos danos.

Nesse sentido, os EUA também são um espaço de experimentação e desenvolvimento social, não necessariamente via Estado, de práticas restaurativas. No Brasil, instituições como Poder Judiciário e Ministério Público vem manifestando interesse crescente em meios dialógicos de resolução de conflitos. Assim, a Resolução n 118 de 2014 do CNMP, que trata da Política de Incentivo à Autocomposição, e a referida Resolução n 225 de 2016 do CNJ, que trata da Política Judicial de Incentivo e Difusão da Justiça Restaurativa, são normas que merecem maior atenção também por reconhecer que a "paz social” deve deixar de ser um conceito abstrato e parcial para ser construída de baixo para cima, e não apenas no inverso.

Por fim, nota-se que a relevância dos direitos das vítimas vem aumentando no Brasil, tendo-se como indícios desse movimento a proposta do Projeto de Lei (PL) $n^{\circ}$ 65/2016, que trata do Ato Nacional dos Direitos das Vítimas de Crimes, e o recente PL n 3890 de 2020, chamado de Estatuto das Vítimas, que inclusive prevê dentre os seus direitos a possibilidade de participação direta ou via representante em práticas restaurativas.

\section{CONCLUSÃO}

Pelo exposto, resta claro que os dois países conferem ao ofendido uma série de prerrogativas no seio do processo e, inclusive previamente a ele, durante as etapas investigatórias. Nos EUA, pela maior força da cultura da negociação no processo penal e pela forte presença dos movimentos pelos direitos dos ofendidos, há a previsão de possibilidades de participação direta do ofendido inclusive durante o plea barganing, o que no caso do acordo de não-persecução penal brasileiro inexiste.

Como nos EUA os estados possuem autonomia para legislar em matéria penal, observou-se que em alguns pontos a tutela dos direitos do ofendido recebe maior ou menor atenção, especialmente no que toca à configuração de direitos mandamentais, ou discricionários, bem como às especificações relativas a remédios processuais para pleitear a efetivação destes direitos, enquanto no Brasil, como a competência para legislar é centralizada na União, há uma 
uniformidade dessa tutela e mesmo sem a previsão específica de remédios processuais, como em certos casos nos EUA, a existência do mandado de segurança supriria tal carência.

Conclui-se também que o direito nos EUA é mais permissivo quanto à participação direta do ofendido no processo, prevendo as declarações de impacto, o direito de conferência com o promotor e o direito de consulta no âmbito do plea bargaining, mas no que concerne à intervenção indireta processual através da defesa técnica, o direito brasileiro oferece ao ofendido chances muito mais potentes dele auxiliar na persecução penal e influenciar os resultados do processo, podendo, inclusive, substituir o Ministério Público em casos de inércia.

Em todo caso, em ambos os países cada vez mais os ofendidos estão logrando espaço no processo penal. Porém, as intervenções processuais e os direitos das vítimas estão ainda atrelados à uma racionalidade punitiva e não representam, nesse sentido, uma mudança de paradigma em relação à tutela penal. Caminho alternativo e distinto das "negociações" é aquele das práticas restaurativas, as quais devem partir de outras premissas em relação ao protagonismo do ofendido e ao conceito de reparação. Aceitar o desafio de dialogar sob racionalidade restaurativa permitiria aos ofendidos um espaço digno e muito mais interessante e desafiador do que a mera atuação na assistência ao órgão de acusação.

\section{REFERÊNCIAS}

AARONSON, David E. New Rights and Remedies: The Federal Crime Victims Rights Act of 2004. Pace Law Review, Symposium Victims and The Criminal Justice System, Issue 4, v. 28, p. 623682, Summer 2008.

ARIZONA. Criminal Code of Arizona (Title 13). Congresso Estadual do Arizona. Disponível em: https://www.azleg.gov/arsDetail/?title=13. Acesso em 29 de dezembro de 2018.

AZEVEDO, André Mauro Lacerda. 0 bem jurídico e os crimes de perigo abstrato. Em: AZEVEDO, André Mauro Lacerda; FACCINI NETO, Orlando. 0 bem jurídico-penal: duas visões sobre a legitimação do Direito Penal a partir da teoria do bem jurídico. Porto Alegre: Livraria do Advogado, p. 15-80, 2013.

BARROS, Flaviane de Magalhães. A Participação da Vítima no Processo Penal. Rio de Janeiro: Lumen, 2008.

BELOOF, Douglas E. Constitutional Implications of Crime Victims as Participants. Cornell Law Review, Volume 88, Issue 2, article 2, p. 282-305, January 2003.

BELOOF, Douglas E. The Third Wave of Crime Victim's Rights: Standing, Remedy, and Review. BYU Law Review. Article 1, Issue 2, p. 256- 365, 2005. 
BITTENCOURT, Edgard de Moura. Vítima. São Paulo: Editora Universitária de Direito Ltda., 1978.

BONFIM, Edilson Mogenout. Curso de Processo Penal. 6ª ed. atual. São Paulo: Atlas, 2011.

BRASIL. Constituição da República do Brasil de 1988. Brasília: Congresso Nacional, 1988.

BRASIL. Lei n 12.850, de 2 de Agosto de 2013. Brasília: Congresso Nacional, 2013.

BRASIL. Lei n 13.964, de 2019. Brasília: Congresso Nacional, 2019.

BRASIL. Lei n³.689, de Outubro de 1941. Brasília: Congresso Nacional. 1941.

BRASIL. Projeto de Lei n 7.006 de 2006. Distrito Federal: Câmara dos Deputados, 2006.

BRASIL. Projeto de Lei n8.045 de 2010. Distrito Federal: Câmara dos Deputados, 2006.

BRASIL Súmula n. ${ }^{\circ} 210$ do Supremo Tribunal Federal. Brasília: Supremo Tribunal Federal, 13 de dezembro de 1963.

BRASIL. Recurso Extraordinário 251445 GO. Supremo Tribunal Federal: Relator Min. Celso de Mello, 21 de junho de 2000. Disponível em: https://stf.jusbrasil.com.br/jurisprudencia/14825705/recurso-extraordinario-re-251445-go-stf.

BRASIL. Resolução $\mathrm{n}^{\circ} 118$ de $1^{\circ}$ de dezembro de 2014. Brasília: Conselho Nacional do Ministério Público, 2014.

BRASIL. Resolução $n^{\circ} 125$ de 29 de novembro de 2010. Brasília: Conselho Nacional de Justiça, 2010.

BRASIL. Resolução $n^{\circ}$ 225, de 31 de maio de 2016. Brasília: Conselho Nacional de Justiça, 2016.

BRASILEIRO, Renato. Manual de Processo Penal. 4 $4^{\mathrm{a}}$ ed. Salvador: Juspodvim, 2016.

CHRISTIE, Nils Conflict as property. The British Journal of Criminology, Oslo, vol. 17, 1977.

CORDEIRO, Euller Xavier Cordeiro. A participação da Vítima no Processo Penal. Franca: Dissertação apresentada à Faculdade de Ciências Humanas e Sociais da Universidade Estadual Paulista, 2014.

COUTINHO, Jacinto Nelson de Miranda. A Lide e o Conteúdo do Processo Penal. Curitiba: Juruá, 1989.

DUBBER, Markus Dirk. The Victim in American Penal Law: A Systematc Overview. Buffalo Criminal Law Review: Victim in Penal Law. Bufflalo: Oct. 21, vol. 3:3, p. 3-31, 1999.

ESTADO DO ARIZONA. Constituição Estadual do Arizona. Congresso Estadual do Arizona: 1911. 
ESTADOS UNIDOS. 18, Part II, Chapter 237, of U.S.C. § 3771. Congresso Nacional: 2004.

ESTADOS UNIDOS. Leeke v. Timmerman, 454 EUA 83 (1981). Suprema Corte: 1981. Disponível em: https://supreme.justia.com/cases/federal/us/454/83/.

FLYNN, Asher. Bargaining with justice: victims, plea bargaining and the Victims' Charter act 2006 (VIC). Monash University Law Review, Vol 37, n. 3, p. 73- 96, 2011.

JARDIM, Afrânio Silva. Ação Penal Pública: Princípio da Obrigatoriedade. Rio de Janeiro: Forense, 1988.

LAW SCHOOL CASE BRIEFS. Linda R. S. v. Richard D. case Summary. Jan, 2013. Disponível em: http://www.lawschoolcasebriefs.net/2013/01/linda-rs-v-richard-d-case-summary.html.

LOUISIANA. Rev Stat § 46:1842. Congresso Estadual de Louisiana: 1985.

MALAQUIAS. A função social do processo no estado democrático de direito. $3^{a}$ reimpressão. Curitiba: Juruá, 2012.

MAYR, Eduardo. Atualidade e Vitimologia. Em: Kosovski, Ester; MAYR, Eduardo; PIEDADE JR., Heitor. Vitimologia em debate. Rio de Janeiro: Editora Forense, p. 11-23, 1990.

NICHOLS, MATTHEW. No One Can Serve Two Masters: Arguments Against Private Prosecutors. Capital Defense Journal: Volume 13, Issue 2, p. 279-305, Spring -3-1-2001.

NUNES DA SILVEIRA, Marco Aurélio. As condições da ação no direito processual penal: sobre a inadequação das condições da ação processual civil ao juízo de admissibilidade da acusação. Florianópolis: Empório do Direito, 2016.

O' HEAR, Michael M. Plea Bargaining and Victims: from consultation to guidelines. Marquette Law Review. Volume 91, Issue 1 Symposium: Dispute Resolution in Criminal Law, Article 14, 323347, 2007.

PALMER, John Gregory. Burdeau v. McDowell, 256 U.S. 465 (1921). 2012. Disponível em: http: / /uscivilliberties.org/cases/3261-burdeau-v-mcdowell-256-us-465-1921.html

PRANIS, Kay; BOYES-WATSON, Carolyn. No Coração da Esperança: guia de práticas circulares. Porto Alegre: Tribunal de Justiça do Estado do Rio Grande do Sul, 2011.

STEVENS, Mark Victim Impact Statements Considered in Sentencing. Berkeley Journal of Criminal Law. Volume 2, Issue 1, article 3, p. 1-13, 2000.

TOURINHO FILHO, Fernando da Costa. Manual de processo penal. $9^{a}$ ed. rev. e atual. São Paulo: Saraiva.

VIDOTTO, Guilherme Santos. O assistente de acusação à luz da Constituição de 1988. Jus.com.br: 2017. Disponível em: https://jus.com.br/artigos/58991/o-assistente-de-acusacao-aluz-da-constituicao-federal-de-1988/6 
YARED, Christiane. Sancionada lei que endurece pena para motorista bêbado que dirige e mata. 20 de dezembro de 2017. Disponível em: https://christianeyared.com.br/sancionada-leique-endurece-pena-para-motorista-bebado-que-dirige-e-mata/.

ZAFFARONI, Eugênio Raúl. Poder Judiciário: Crise, Acertos e Desacertos. São Paulo: Editora Revista dos Tribunais, 1995.

Recebido em: 04/11/2019 / Aprovado em: 25/11/2021 / Publicado em: 30.11.2021

\section{COMO FAZER REFERÊNCIA AO ARTIGO (ABNT):}

GIAMBERARDINO, André Ribeiro; SILVA, Mário Edson Passerino Fischer da. Sobre o tratamento legal do ofendido no processo penal: uma análise comparativa entre o direito brasileiro e o norte-americano. Revista Eletrônica do Curso de Direito da UFSM, Santa Maria, RS, v. 16, n. 1, e40933. 2021. ISSN 1981-3694. DOI: http://dx.doi.org/10.5902/1981369440933. Disponível em: https://periodicos.ufsm.br/revistadireito/article/view/40933. Acesso em: dia mês. ano.

Direitos autorais 2021 Revista Eletrônica do Curso de Direito da UFSM

Editores responsáveis: Rafael Santos de Oliveira e Angela Araujo da Silveira Espindola

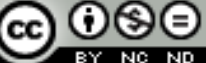

Esta obra está licenciada com uma Licença Creative Commons Atribuição-NãoComercial-SemDerivações 4.0 Internacional.

\section{SOBRE OS AUTORES}

ANDRÉ RIBEIRO GIAMBERARDINO

Professor dos Programas de Pós-graduação em Direito e em Sociologia da Universidade Federal do Paraná (UFPR) e atual Coordenador do Núcleo de Política Criminal e Execução Penal da Defensoria Pública do Paraná. É Coordenador da CAJEP/UFPR (Clínica de Acesso à Justiça e Educação nas Prisões - UFPR). Foi "Visiting Scholar" na Columbia Law School - Nova York (CAPES-PRINT) entre dezembro de 2019 e junho de 2020; Chefe de Gabinete do Ministério da Segurança Pública (2018) e Subdefensor Público Geral do Estado do Paraná (2013-2015). É membro titular do Conselho Penitenciário do Paraná e do Conselho Estadual de Segurança Pública do Paraná. Doutor em Direito do Estado pela UFPR (2014), Mestrado em Direito pela UFPR e Especialização em Criminologia pela Università degli Studi di Padova e pelo ICPC/PR.

MÁRIO EDSON PASSERINO FISCHER dA SILVA

Mestre (2018-2020) e bacharel em Direito (2012-2018) pela Universidade Federal do Paraná (UFPR). Foi estudante intercambista bolsista do curso de direito da Alma Mater Studiorum Università di Bologna em 2015. Pesquisa temas relacionados a técnicas autocompositivas, justiça restaurativa, processo penal, negociação e criminologia, tendo realizado treinamentos e publicado artigos sobre esses assuntos. Tem experiência com o desenvolvimento e execução de projetos envolvendo a prática e a implementação de fluxos autocompositivos para abordagem de conflitos de diversas naturezas. Está habilitado como facilitador de práticas restaurativas e como conciliador judicial pelo Tribunal de Justiça do Estado do Paraná, bem como como instrutor de práticas restaurativas pelo Ministério Público do Estado do Paraná (MPPR). Atua como assessor jurídico do MPPR desde 2018, estando atualmente lotado no Núcleo de Prática e Incentivo à Autocomposição e integrando o Grupo de Pesquisa em Métodos Autocompositivos do MPPR. Leciona no curso de pós-gradução latu sensu em Justiça Restaurativa e Mediação de Conflitos do Centro Universitário Santa Amélia desde 2020. Atua como um dos tutores do Grupo de Pesquisa em Métodos Autocompositivos do MPPR desde 2018 e desde 2021 passou a integrar o Grupo de Pesquisa USP Restaura, voltada ao estudo crítico da Justiça Restaurativa no contexto brasileiro. 